\title{
PENGARUH PENANGANAN PASCAPANEN TERHADAP MUTU DAN KEAMANAN PANGAN BIJI KAKAO
}

\author{
The Effect of Postharvest Handling on Quality and Food Safety \\ of Cocoa Beans
}

\author{
S. Joni Munarso ${ }^{\text {a) }}$, Miskiyaha) ${ }^{\text {a }}$ dan M. Thamrin ${ }^{\text {b) }}$ \\ a) Balai Besar Penelitian dan Pengembangan Pascapanen Pertanian \\ Jl. Tentara Pelajar No 12, Bogor 16114 \\ b) Balai Pengkajian Teknologi Pertanian Sulawesi Selatan \\ Jl. Perintis Kemerdekaan Km 17,5 Sudiang PO BOX 1234, Makassar 90242 \\ Pos-el: jomunarso@gmail.com, miski_pascapanen2005@yahoo.co.id \\ (Artikel diterima 15 Januari 2016 ; direvisi 24 Mei 2016 ; disetujui 30 Mei 2016)
}

\begin{abstract}
Production of cocoa beans increasing significantly, but the quality of the seeds low and varied. The main problem is because of the cocoa farmers generally did not apply the recommended technique for cultivation and postharvest handling. The aims of this study was to observe the effect of GAP and GMP application to the quality and safety of cocoa beans produced by farmer groups. To achieve the above objectives, a study has been conducted in Tinco, District Citta, Soppeng South Sulawesi Province. This activity was done by involving farmer groups with different cultivation technology. The activity included: 1 . Study to identify the performance of cocoa cultivation; 2. analysis of the effect of GAP and GMP application to quality and safety of cocoa beans produced by farmer groups. The results showed that the quality of cocoa beans produced by Bunga coklat farmer group better than Mattirodeceng farmer group; the application of GAP and GMP increased the quality of cacao beans. Model application of GAP and GMP system at Bunga coklat farmer group can be used as a sample of cocoa farm production, quality and sustainability oriented.
\end{abstract}

Keywords : postharvest handling, quality, food safety, cocoa

\begin{abstract}
Abstrak: Produksi biji kakao secara signifikan terus meningkat, namun mutu bijinya tergolong rendah dan beragam. Masalah mutu ini utamanya disebabkan karena petani kakao pada umumnya tidak menerapkan sistem budidaya tanaman maupun teknologi pascapanen yang dianjurkan. Tujuan dari penelitian ini adalah untuk mengamati pengaruh penerapan teknik budidaya serta penerapan teknologi fermentasi terhadap mutu dan keamanan biji kakao yang dihasilkan oleh petani. Untuk mencapai tujuan di atas, telah dilakukan suatu kegiatan riset di Desa Tinco, Kecamatan Citta, Kab. Soppeng, Provinsi Sulawesi Selatan. Kegiatan tersebut melibatkan kelompok tani dengan penguasaan teknologi budidaya yang berbeda. Adapun kegiatan yang dilakukan meliputi (1) Studi untuk mengetahui keragaan teknologi budidaya kakao, dan (2) Analisis pengaruh penerapan GAP dan GMP terhadap mutu biji kakao hasil produksi petani. Hasil penelitian menunjukkan bahwa penerapan GAP dan GMP mampu meningkatkan mutu dan keamanan pangan biji kakao yang dihasilkan oleh kelompok tani. Penerapan sistem tersebut berpotensi dikembangkan di wilayah produsen kakao. Model ini perlu dikembangkan pada usahatani kakao yang berorientasi pada produksi, mutu dan berkelanjutan.
\end{abstract}

Kata kunci : pengananan pascapanen, mutu, keamanan pangan, kakao

\section{PENDAHULUAN}

Kakao merupakan komoditas andalan ekspor hasil perkebunan yang utama di Indonesia. Indonesia merupakan salah satu dari 3 negara pengekspor biji kakao terbesar di dunia. Berdasarkan data ICCO (International Cocoa Organization) Indonesia merupakan produsen biji kakao nomor tiga dunia setelah Pantai Gading dan Ghana. Tahun 2009 produksi biji kakao Pantai Gading sebesar 1.270.226 ton, Ghana 830.790 ton dan Indonesia sebesar 737.989 ton. Namun kenyataannya industri pengolahan kakao dan industri cokelat justru berada di negara-negara Eropa (Belgia, Inggris, dan Swiss), Amerika Serikat, serta Singapura dan Malaysia sehingga nilai tambah tidak dinikmati Indonesia sebagai penghasil biji kakao. Mutu komoditas kakao menjadi permasalahan utama dalam daya saing dengan negara lain, 
terutama dengan adanya indikasi tercemarnya produk dengan logam berat.

Perdagangan biji kakao seringkali mengalami berbagai hambatan teknis, diantaranya mutu biji kakao. Permasalahan mutu biji kakao yang menjadi penghambat dalam perdagangan antara lain adanya kotoran, serangga, biji tidak terfermentasi sempurna, adanya kontaminan mikotoksin dan logam berat, dll yang sering ditemukan kakao baik pada biji maupun produk olahannya. Masalah keragaman mutu ini utamanya disebabkan karena petani kakao tidak menerapkan sistem budidaya tanaman yang dianjurkan (Hariyadi et al, 2009). Beberapa teknologi budidaya belum dilakukan dengan benar, seperti teknologi penggunaan varietas unggul, pemupukan, penggunaan tanaman naungan, maupun pemangkasan. Penggunaan pestisida banyak dilakukan untuk mengendalikan hama dan penyakit pada kakao (Owuhu Ansah et al, 2010). Teknologi panen dan penanganan pascapanen juga belum dilakukan secara optimal. Proses fermentasi terhadap biji hasil panen dilakukan secara asal-asalan atau bahkan tidak dilakukan sama sekali (Magelhaes et al, 2011).

Secara teknis operasional, keragaman mutu kakao disebabkan oleh minimnya sarana penerapan teknologi budidaya dan pengolahan, serta lemahnya pengawasan mutu pelaksanaan proses produksi kakao rakyat. Kriteria mutu biji kakao yang meliputi aspek fisik, cita rasa, kebersihan, aspek keseragaman dan konsistensi sangat ditentukan oleh perlakuan pada setiap tahapan proses produksi tersebut. Oleh karena itu pengawasan dan pemantauan pada setiap tahapan proses mestinya dilakukan secara rutin agar tidak terjadi penyimpangan mutu.

Pemerintah telah menetapkan standar mutu kakao (SNI 01-2323-2008) (Anonim, 2008), dalam bentuk penetapan kelas mutu biji kakao. Penerapan teknik budidaya dan pascapanen yang baik diharapkan bukan hanya memperbaiki mutu kakao yang dihasilkan, tetapi juga akan membantu upaya peningkatan produktivitas kakao. Sistem jaminan keamanan pangan merupakan persyaratan utama dalam parameter mutu pangan, dan telah menjadi acuan bagi perdagangan pangan domestik maupun internasiona (Winarno, 2002). Salah satu bentuk manajemen risikoyang dikembangkan untuk menjamin keamanan pangan dengan pendekatan pencegahan (preventive) adalah HACCP (Montimore, 1998). Penerapan HACCP dapat disederhanakan sampai pada level dimana dapat diintegrasikan dengan proses pengolahan yang sederhana atau tradisional, dengan pengujian yang dapat dilakukan secara visual (Amoa_Awua et al, 2008). Good Agricultural Practices (GAP) dan Good Manufacturing Practices (GMP) merupakan persyaratan dasar (prerequisite) yang harus dipenuhi jika ingin menerapkan HACCP (Amoa_Awua et al, 2007 dan Babunja_Sonie et al, 2011). Tujuan dari penelitian ini adalah untuk mempelajari tingkat penguasaan teknologi budidaya dan pascapanen, serta pengaruh penerapan GAP dan GMP terhadap mutu dan keamanan biji kakao yang dihasilkan oleh kelompok tani.

\section{METODOLOGI}

\section{Bahan dan Alat Penelitian}

Penelitian dilakukan pada kurun Februari-November 2012. Lokasi penelitian ditetapkan melalui koordinasi antara Tim Peneliti dengan Balitbangda Provinsi Sulawesi Selatan, BPTP Sulawesi Selatan, serta Dinas Perkebunan Kabupaten Soppeng, dengan memperhatikan bahwa lokus adalah daerah penghasil utama kakao. Kegiatan penelitian melibatkan kelompok tani "Bunga Coklat" dan kelompok tani "Mattirodeceng" desa Tinco kecamatan Citta Kabupaten Soppeng. Pengambilan sampel untuk pengujian mutu dan keamanan pangan biji kakao (residu pestisida) juga dilakukan terhadap 2 kelompok tani tersebut. Peralatan yang digunakan adalah tabung reaksi, gelas piala, erlenmeyer, pinset, timbangan, serta peralatan preparasi dan peralatan gelas lainnya dan peralatan uji laboratorium (GC MS, HPLC, dll).

\section{Metode Penelitian \\ Obyek penelitian adalah kelompok tani penghasil kakao yang dibedakan}


dalam 2 kelompok, yaitu kelompok yang telah menerapkan GAP (Kelompok Tani "Bunga Coklat") dan kelompok yang belum menerapkan GAP (Kelompok "Mattirodeceng"). Penelitian diawali dengan melakukan identifikasi tingkat penguasaan teknologi budidaya dan pascapanen pada kedua kelompok tani tersebut. Sosialisasi dan pengenalan GAP budidaya kakao serta GMP penanganan pascapanen dilakukan terhadap kelompok tani target. Pengambilan sampel dilakukan setelah petani melakukan penerapan GAP dan GMP setelah tahapan sosialisasi dan dilakukan analisis mutu dan keamanan pangan (residu pestisida) biji kakao.

Analisis mutu dilakukan mengikuti prosedur yang terurai pada Standar Mutu Biji Kakao (SNI 01-2323-2008). Analisis kimia juga dilakukan untuk mengetahui kadar lemak, kadar protein dan kadar polifenol biji kakao hasil dari kedua kelompok. Pengamatan parameter keamanan pangan dilakukan terhadap residu pestisida dari kelompok Organoklorin, Organofosfat dan Piretroid. Analisis dilakukan di beberapa laboratorium, antara lain di laboratorium Balai Tanaman Obat dan Rempah (Balittro), Laboratorium Balai Penelitian Lingkungan Pertanian (Balingtan), dan Laboratorium Saraswanti Indogenetech Bogor. Hasil analisis selanjutnya didiskripsikan antara kelompok tani yang sudah dan belum menerapkan GAP dan GMP penanganan kakao.

\section{HASIL DAN PEMBAHASAN}

Keragaan Teknologi Budidaya

Kelompok Tani (Klotan) Bunga Coklat mempunyai tingkat penguasaan teknologi budidaya kakao yang berbeda dengan klotan Mattirodeceng dalam mengusahakan produksi kakao (Tabel 1). Kelompok Bunga Coklat telah menerapkan berbagai komponen teknologi budidaya yang baik, mulai dari penggunaan klon unggul, penyemaian benih, penaungan dan pemangkasan, pola tanam, jarak tanam, drainase dan rorak, pemupukan, sanitasi kebun, pengendalian hama/penyakit, sedangkan kelompok Mattirodeceng baru mulai menerapkan klon unggul. Penerapan teknik budidaya yang baik ini berdampak pada produksi buah per pohon yang sangat berbeda (50-110 banding 15-60 buah) (Tabel 1). Pertanaman kakao di lapang sangat berbeda keragaannya antara kelompok tani Bunga Coklat dan Mattirodeceng. Kelompok tani Bunga Coklat sudah menggunakan klon unggul (S1 dan S2) dari jenis Forastero (Lindak). Sedangkan petani di kelompok tani Mattirodeceng umumnya masih menggunakan klon lokal dari jenis yang sama.

Tabel 1. Keragaan Komponen Teknologi Budidaya Kakao di Kelompok Tani Bunga Coklat dan Mattiro-deceng

\begin{tabular}{|c|c|c|}
\hline Komponen Teknologi & Bunga Coklat & Mattirodeceng \\
\hline Penggunaan Klon Unggul & $90 \%$ & 1\% (TM); 29\% (TBM) \\
\hline Penyemaian Benih & Sudah Dilakukan & Belum Dilakukan \\
\hline Penaungan/ Pemangkasan & Sesuai & Belum Sesuai \\
\hline Pola Tanam & $\begin{array}{l}\text { Bikultur } \\
\text { (Kakao,Pisang) }\end{array}$ & Monokultur \\
\hline Jarak Tanam & $3 \times 3 \mathrm{~m} 2$ & $\begin{array}{l}2,5 \times 2,5 \mathrm{~m} 2 \text { (tidak } \\
\text { teratur) }\end{array}$ \\
\hline Drainase dan Rorak & Ada & Tidak Ada \\
\hline Pemupukan & 1-3 kali setahun & 1 kali setahun \\
\hline Sanitasi Kebun & Dilakukan & Tidak/Sesekali Dilakukan \\
\hline Pengendalian H\&P & $2 \times /$ bulan & $1 \mathrm{x}$ setahun, atau tidak \\
\hline Produksi buah/pohon & $50-110$ & $15-60$ \\
\hline
\end{tabular}


Klotan Mattirodeceng juga belum menerapkansanitasikebundanrorak.Sanitasi minimal ini ditunjukkan dari banyaknya kulit buah bekas panenan yang berserakan di dalam kebun sehingga kebun tampak kotor dan kumuh. Kondisi ini menjadi salah satu penyebab tingginya serangan hama dan penyakit pada pertanaman kakao. Hama dan penyakit yang banyak dijumpai menyerang buah di kebun petani Mattirodeceng masingmasing adalah penggerek buah kakao (PBK) dan Helopeltis spp., kepik pengisap buah serta penyakit busuk buah yang disebabkan oleh Phytopthora palmivora (Gambar 1).
Serangan ini berpeluang semakin parah, mengingat pengendalian hama penyakit di kelompok ini dilakukan secara minimal.

Pengendalian hama penyakit yang konsisten dilakukan di klotan Bunga Coklat telah menghasilkan produktivitas maupun tampilan buah yang baik. Di kelompok ini, pengendalian hama dan penyakit dilakukan dengan penggunaan pestisida kimia, seperti Alika dan sebagainya, dengan frekuensi penyemprotan satu kali setiap 2 bulan atau 6 kali per tahun. Bandingkan dengan klotan Mattirodeceng yang hanya sekali setahun ataubahkan tidak disemprot (Tabel 1).
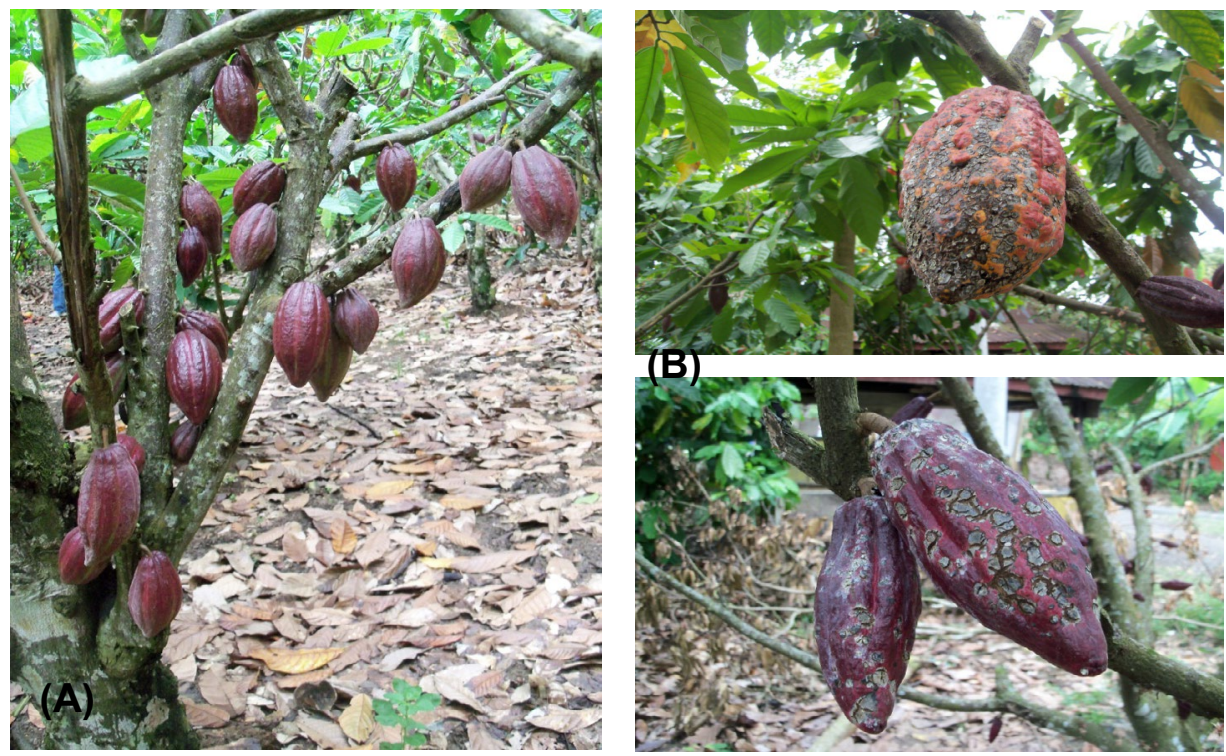

Gambar 1. Kesehatan Buah di Kebun Kelompok Tani Bunga Coklat (A) dan Kelompok Tani Mattiro-deceng (B)

Pada dua kelompok tani juga jelas terlihat adanya perbedaan potensi buah yang dihasilkan, masing-masing dengan produksi 50-110 buah/pohon (petani Bunga Coklat) dan petani Mattirodeceng hanya 15-60 buah/pohon. Produksi buah yang dihasilkan ini juga sangat tergantung dari pemupukan yang diberikan (jenis pupuk, dosis, dan waktu pemberian). Petani Mattirodeceng hanya memberikan pupuk satu kali dalam setahun, jauh lebih sedikit dibanding dengan petani Bunga Coklat sebanyak 3 kali/tahun. Keseluruhan informasi di atas diperoleh melalui kegiatan pemantauan dan pengukuran.

\section{Karakteristik Mutu Biji}

Mutu biji kakao ditetapkan berdasar SNI 3232-2008, yang didalamnya mengandung unsur persyaratan umum dan persyaratan khusus. Pada awal kegiatan, klotan Bunga Coklat maupun Mattirodeceng menghasilkan biji kakao yang sama-sama belum terfermentasi. Meskipun demikian, mutu biji yang dihasilkan berbeda, khususnya pada kriteria mutu 'kadar air'. Klotan Bunga Coklat telah mampu menghasilkan biji dengan kadar air 7,23\% (<7,5\%) sehingga memenuhi persyaratan umum, sedangkan klotan Mattirodeceng belum mampu (Tabel 2). Sementara karakteristik mutu lain, 
seperti serangga hidup, biji berbau asap dan atau hammy dan atau berbau asing, dan kadar benda asing telah sesuai SNI 23232008 (Tabel 3). Adapun pada pengamatan persyaratan khusus, jenis mutu kakao yang dihasilkan kelompok tani ini memenuhi kelas mutu I - II.

Tabel 2. Karakteristik umum Mutu Biji Awal Kakao Klotan Bunga Coklat dan Mattirodeceng

\begin{tabular}{lccc}
\hline \multicolumn{1}{c}{ Karakteristik } & Bunga Coklat & Mattiro deceng & SNI (3232 : 2008) \\
\hline Jumlah biji/100 gr & $96 / 100 \mathrm{~g}(\mathrm{~A})$ & $94 / 100 \mathrm{~g}(\mathrm{~A})$ & * \\
Kadar air (\%) & 7,23 & 7,64 & Maks. 7,5 \\
$\begin{array}{l}\text { Serangga hidup (\%) } \\
\text { Biji berbau asap dan atau hammy } \\
\text { dan atau berbau asing, (\%) }\end{array}$ & 0 & 0 & Tidak ada \\
Kadar benda asing (\%) & 2,1 & 0 & Tidak ada \\
\hline
\end{tabular}

Keterangan : * grade : AA (maksimal 85 biji); A (85 -100); B (101-110); C (111-120); S ( >120)

Tabel 3. Karakteristik khusus Mutu Biji Awal Kakao Klotan Bunga Coklat dan Mattirodeceng

\begin{tabular}{|c|c|c|c|c|c|}
\hline \multirow[t]{2}{*}{ Jenis mutu } & \multicolumn{5}{|c|}{ Persyaratan } \\
\hline & $\begin{array}{l}\text { Kadar biji } \\
\text { berjamur } \\
\text { (biji/biji) }\end{array}$ & $\begin{array}{c}\text { Kadar } \\
\text { biji slaty } \\
\text { (biji/biji) }\end{array}$ & $\begin{array}{c}\text { Kadar biji } \\
\text { berserangga } \\
\text { (biji/biji) }\end{array}$ & $\begin{array}{c}\text { Kadar } \\
\text { kotoran } \\
\text { waste } \\
\text { (biji/biji) }\end{array}$ & $\begin{array}{c}\text { Kadar biji } \\
\text { berkecambah } \\
\text { (biji/biji) }\end{array}$ \\
\hline $\begin{array}{l}\text { Kakao mulia } \\
\text { Bunga Coklat }\end{array}$ & $1,6 / 96$ & $\begin{array}{c}\text { Tidak } \\
\text { dilakukan }\end{array}$ & 0 & $0,33 / 96$ & 0 \\
\hline $\begin{array}{l}\text { Kakao lindak } \\
\text { Mattirodeceng }\end{array}$ & $1,8 / 94$ & $\begin{array}{c}\text { Tidak } \\
\text { dilakukan }\end{array}$ & 0 & $0 / 94$ & 0 \\
\hline $\begin{array}{l}\text { Kakao mulia (Fine } \\
\text { Cocoa) I-F* }\end{array}$ & Maks. 2 & Maks. 3 & Maks. 1 & Maks. 1,5 & Maks. 2 \\
\hline $\begin{array}{l}\text { Kakao mulia (Fine } \\
\text { Cocoa) II }-\mathrm{F}^{*}\end{array}$ & Maks. 4 & Maks. 8 & Maks. 2 & Maks. 2,0 & Maks. 3 \\
\hline $\begin{array}{l}\text { Kakao mulia (Fine } \\
\text { Cocoa) III - F* }\end{array}$ & Maks. 4 & Maks. 20 & Maks.2 & Maks. 3,0 & Maks. 3 \\
\hline $\begin{array}{l}\text { Kakao mulia (Bulk } \\
\text { Cocoa) I - B* }\end{array}$ & Maks. 2 & Maks. 3 & Maks. 1 & Maks. 1,5 & Maks. 2 \\
\hline $\begin{array}{l}\text { Kakao mulia (Bulk } \\
\text { Cocoa) II - B* }\end{array}$ & Maks. 4 & Maks. 8 & Maks. 2 & Maks. 2,0 & Maks. 3 \\
\hline $\begin{array}{l}\text { Kakao mulia (Bulk } \\
\text { Cocoa) III - B* }\end{array}$ & Maks. 4 & Maks. 20 & Maks.2 & Maks. 3,0 & Maks. 3 \\
\hline
\end{tabular}

Keterangan : * SNI 2323:2008

Penerapan GAP dan GMP menunjukkan keragaan mutu biji kakao pada kelompok tani Bunga Coklat mengalami peningkatan dibandingkan dengan kelompok tani Mattirodeceng (Tabel 4).
Hal ini disebabkan karena petani sudah menggunakan varietas unggul/klon mulia, yang umumnya memiliki ukuran biji yang lebih besar dari pada klon lokal. Petani sudah menerapkan praktek fermentasi biji kakao. Hal ini memperbaiki karakter aroma khas kakao, warna biji, mengurangi rasa 
pahit, asam, manis, dan mengeraskan kulit biji seperti tempurung.

Penerapan GAP dan GMP yang dilakukan dengan baik dan benar dapat memperbaiki sifat kadar air dari biji kakao yang dihasilkan. Tabel 2 menunjukkan kadar air kakao kedua kelompok tani memenuhi persyaratan SNI. Namun demikian, kemampuan untuk melakukan pengeringan yang lebih baik nampak lebih dikuasai oleh kelompok tani Bunga Coklat, dengan menghasilkan kadar air yang lebih rendah. Berdasarkan persyaratan khusus, kedua kelompok tani juga telah mampu memenuhi standar mutu SNI. Kelas mutu biji kakao yang dihasilkan termasuk pada kelas mutu I - II (Tabel 3). Perbedaan yang nyata dari kedua kelompok ini terletak pada kemampuan petani dalam melakukan fermentasi biji kakao. Kelompok tani Bunga Coklat mampu menghasilkan kualitas biji yang lebih baik dibandingkan dengan kelompok tani Mattirodeceng dengan mulai diterapkannya proses fermentasi dalam penanganan biji kakao.

\section{Karakteristik Kimia dan Keamanan Biji Kakao}

Karakteristik kimia dinyatakan melalui pengukuran kadar lemak dan kadar protein biji kakao. Sementara karakter keamanan pangan ditunjukkan oleh adanya residu pestisida. Kedua karakter ini tidak termasuk dalam persyaratan SNI, namun penting diketahui karena terkait dengan proses pengolahan yang dilakukan dan keamanan produk yang akan dihasilkan. Pada Tabel 4 ditunjukkan bahwa kadar protein dan kadar lemak kakao yang dihasilkan petani Bunga Coklat lebih tinggi dibandingkan dengan petani Mattirodeceng. Hal ini terkait dengan menurunnya kandungan serat pada biji akibat proses fermentasi yang dilakukan oleh kelompok tani Bunga Coklat.

Kadar polifenol biji kakao yang dihasilkan klotan Bunga Coklat ternyata lebih tinggi daripada kadar polifenol pada biji kakao dari klotan Mattirodeceng (Tabel 4). Hal ini sangat terkait dengan faktor perbedaan klon dan adanya proses fermentasi yang dilakukan oleh klotan Bunga Coklat. Proses fermentasi diketahui mampu meningkatkan kadar polifenol, zat yang bermanfaat sebagai antioksidan, dan mempunyai aktivitas antilisteria, sehingga kakao berpotensi digunakan sebagai alternatif food aditif untuk mencegah pembusukan dan kontaminasi Listeria monocytogenes (Bubonja-Sonie et.al, 2011).

\section{Tabel 4. Karakteristik Kimia Biji Kakao di Kelompok Tani Bunga Coklat dan Mattirodeceng}

\begin{tabular}{lcc}
\hline Komponen & Bunga coklat & Mattirodeceng \\
\hline $\begin{array}{l}\text { Kadar Lemak } \\
(\%)\end{array}$ & 35,51 & 34,73 \\
$\begin{array}{l}\text { Kadar Protein } \\
(\%)\end{array}$ & 16,27 & 14,84 \\
Polifenol (\%) & 44,36 & 39,45 \\
\hline
\end{tabular}

Analisis residu pestisida pada biji kakao menunjukkan adanya beberapa komponen kimia dalam biji kakao. Pada Tabel 5 nampak bahwa biji kakao yang dihasilkan oleh kelompok tani Bunga Coklat mengandung residu pestisida dengan beragam komponen dan dalam jumlah yang bervariasi. Sementara itu, kandungan residu pestisida dalam biji kakao yang dihasilkan oleh klotan Mattirodeceng lebih terkonsentrasi pada jenis Organofosfat. Keadaan ini sangat terkait dengan frekuensi penggunaan pestisida yang biasa dilakukan oleh petani. Proses fermentasi yang dilakukan oleh klotan Bunga Coklat nampaknya belum cukup untuk menekan residu tersebut. Namun kepastiannya perlu didukung oleh percobaan laboratorium yang lebih terkontrol.

Pengujian residu pestisida pada kakao menunjukkan bahwa residu lindan juga terdeteksi pada penelitian yang dilakukan oleh Owushu-Manu (1977) dengan kisaran 0,14-0,25 ppm, dengan rataan 0,18 ppm. Umpan balik yang diperoleh dari informasi ini antara lain perlunya langkah sosialisasi yang lebih mendalam terkait penerapan pestisida secara bijaksana. Selain itu, penjajakan terhadap kemungkinan penggunaan pestisida nabati juga diperlukan.

Kualitas kakao baik dari segi mutu dan keamanan merupakan hal yang 
terpenting bagi kakao. Sehingga petani perlu meningkatkan praktek penerapan GAP dan GMP sesuai dengan rekomendasi. Quarmine et al (2012), bahwa kualitas premium kakao tidak akan bisa dicapai tanpa penerapan uji kualitas, serta kebijakan penerapan mekanisme insentif diperlukan. Hal yang sama perlu dilakukan oleh pemerintah, sehingga mendorong petani untuk menerapkan GAP dan GMP dalam produksi kakaonya.

Tabel 5. Keragaan Komponen Keamanan Pangan (Residu Pestisida) Kakao di Kelompok Tani Bunga Coklat dan Mattirodeceng

\begin{tabular}{|c|c|c|c|}
\hline Komponen & $\begin{array}{l}\text { Bunga } \\
\text { Coklat }\end{array}$ & $\begin{array}{l}\text { Mattiro- } \\
\text { deceng }\end{array}$ & $\begin{array}{c}\text { LD } \\
(\mathrm{mg} / \\
\mathrm{kg})\end{array}$ \\
\hline \multicolumn{4}{|l|}{ Organoklorin } \\
\hline Lindan & 0,011 & $<\mathrm{LD}$ & 0,010 \\
\hline Aldrin & 0,014 & $<L D$ & 0,008 \\
\hline Heptaklor & 0,019 & $<$ LD & 0,010 \\
\hline \multicolumn{4}{|l|}{ Organofosfat } \\
\hline Diazinon & $<$ LD & 0,020 & 0,010 \\
\hline Metidation & 0,017 & 0,011 & 0,010 \\
\hline Klorpirifos & 0,014 & 0,013 & 0,010 \\
\hline Profenofos & 0,022 & $<$ LD & 0,010 \\
\hline Dimetoat & 0,011 & $<$ LD & 0,010 \\
\hline Piretroid & $\begin{array}{c}\text { Semua } \\
\text { komponen } \\
\text { di bawah } \\
\text { LD }\end{array}$ & $\begin{array}{c}\text { Semua } \\
\text { komponen } \\
\text { di bawah } \\
\text { LD }\end{array}$ & \\
\hline
\end{tabular}

Keterangan: LD : Limit Deteksi

\section{SIMPULAN}

1. Kualitas biji kako yang dihasilkan oleh kelompok tani Bunga Coklat lebih baik dibandingkan dengan kelompok tani Mattirodeceng yang sudah melakukan penerapan GAP dan GMP dan budidaya dan penanganan pascapanen kakao.

2. Penerapan sistem GAP dan GMP fermentasi kakao berpotensi dikembangkan di wilayah produsen kakao karena dapat meningkatkan kualitas biji kakao.

3. Model penerapan sistem GAP dan GMP di kelompok tani Bunga Coklat diharapkan dapat menjadi percontohan bagi berbagai pihak yang ingin mengembangkan usahatani kakao yang berorientasi pada produksi, mutu dan berkelanjutan.

\section{UCAPAN TERIMA KASIH}

Ucapan terima kasih disampaikan kepada Badan Litbang Pertanian yang telah membiayai kegiatan penelitian ini.

\section{DAFTAR PUSTAKA}

1. Amoa-Awua, WK, Halm, A., Jakobsen, M. 1998. HACCP System for African fermented foods: kenkey. Taastrup, Denmark: World Association of Industrial and Tachnological Research Organizations.

2. Amoa-Awua, WK, Ngunjiri, P., Anlobe, J., Kpodo, K.,Halm, M., Hayford, AE., dan Jakobsen, M. 2007. The effect of applying GMP and HACCP to traditional food processing at semi-commercial kenkey production plant in Ghana. Food Control : 18 : 1449-1457.

3. Anonim. 2008. SNI 2323 : Biji Kakao. Badan Standardisasi Nasional. Jakarta. 41 halaman.

4. Bubonja-Sonie M, Giacometti, J, Abram M. 2011. Antioxidant and antilisterial activity of olive oil, cocoa and rosemary extract polyphenols. Food Chemistry : 127:4:1821-1827.

5. Hariyadi, Sehabudin, H., Winasan, IW. 2009. Identifikasi Permasalahan dan Solusi Pengembangan Perkebunan Kakao Rakyat di Kabupaten Luwu Utara, Provinsi Sulawesi Selatan. Prosiding Seminar Hasil-Hasil Penelitian IPB. Hal 75-88.

6. Magalhães, JT, George Andrade Sodré, Henry Viscogliosi, Marie-Florence Grenier-Loustalot. 2011. Occurrence of Ochratoxin A in Brazilian cocoa beans. Food Control 22 : $744-748$.

7. Maharaj, R. 2010. HACCP-based System and The Cocoa Value Chain. University of Trinidad Tobago.

8. Montimore, S. dan Wallace, C. 1998. HACCP a practical approach. 
Gaithersburg, Maryland USA. Aspen Publisher Inc.

9. Owansu-Manu, E. 1977. Insecticide Residue and Tainting in Cocoa. Pesticide managemenat and Insecticide Resistance. Academic Press : 555-564.

10. Owuhu-Ansah, E, Koranteng-Addo, JE, Boamposem, LK, Menlah, E, Abole, E. 2010. Assessment of Lindane pesticide residue in Cocoa beans in the Twifo Praso district of Ghana. J. Chem. Pharm. Res : $2: 4: 580-587$.
11. Qurmine, W, Haagsma, R, SakyiDawson, O, Asante, F, van Huis, A, Obeng-Oforo,D. 2012. Inventive for cocoa bean production in Ghana : Does Quality matter. NJAS:Wageningen Journal of Life Science: 60-63:7-14.

12. Winarno, FG. 2002. Codex dan SNI dalam Perdagangan Pangan Global. MBRIO Press. Cetakan 1. 75 hal. 